\title{
Márfy Anna
}

\section{Önismeret az önmegvalósításban a grafológia eszközeivel}

\author{
Anna Márfy: Self- knowledge in the self realization with graphology means
}

\begin{abstract}
The personality influences our everyday lives. Because different needs achieving drive us. But many people ask the question; Where to go? What should I do? If we have the appropriate level of self-awareness, then we can answer these questions. So, it is important to talk about what we can do to get to know ourselves. This is especially important for young people faced with career choices. If you want to be professionally characterization, graphology is a great help. Keyword: needs, self-knowledge, self-realization, graphology
\end{abstract}

\section{ÖSSZEFOGLALÓ}

A személyiségünk befolyásolja a mindennapjainkat. Hiszen más- más szükséglet elérése hajt minket. De sokan teszik fel a kérdést; Merre menjek? Mit csináljak? Ha megfelelő szintű önismerettel rendelkezünk, akkor meg tudjuk válaszolni ezeket a kérdéseket. Így fontos beszélni arról, hogy mit is tudunk tenni azért, hogy megismerjünk önmagunk. Ez kifejezetten fontos a pályaválasztás előtt álló fiatalok számára. $\mathrm{Ha}$ pedig szakszerűen akarunk jellemzést adni, nagy segítségünkre van a grafológia.

Kulcsszavak: szükségletek, önismeret, önmegvalósítás, grafológia

“Az embernek harmóniában kell élnie önön természetével. Ehhez elöbb meg kell ismernie önmagát, majd a felismert igazságokhoz kell igazítania az életét."

(C.G. Jung)

Az ember hosszú földi élete során minden módot, eszközt és lehetőséget megragad annak érdekében, hogy a benne rejlő ösztönkésztetéseket, adottságokat, képességeket kifejezésre juttassa, önmagát valamilyen módon megvalósítsa, a környezetében élők szeretetét, elismerését megkapja és azt viszonozza.

C.Rogers - a humanisztikus pszichológiai irányzat képviselője szerint -: „Az ember veleszületett tendenciával rendelkezik a személyes fejlődésre, az éretté válásra és a pozitív változásra ... az emberi szervezet alapvető motiváló ereje az önmegvalósitás egy késztetés a szervezet minden potenciális képességének kiteljesitésére." [8] [13]

Mivel az ember alapvetően szabadnak született eldöntheti, hogy TELJESEBBÉ válása, élete, önmegvalósítása piramisára meddig, hogyan és milyen kitérőkkel akar feljutni.
A. Maslow - aki C. Rogershez hasonlóan a humanisztikus pszichológiai irányzatot képviselte - felállította az ember szükséglethierarchia piramisát. [8]
Ezt láthatjuk az 1. ábrában.

Képletesen: A személyiség (lásd: Alapfogalmak) dönthet úgy, hogy a piramis alsó szintjén maradva, testi örömöknek hódolva, a napi túlélésre berendezkedve él, vagy nagyobbat álmodva - megismerve önmagát - elindul felfelé. 


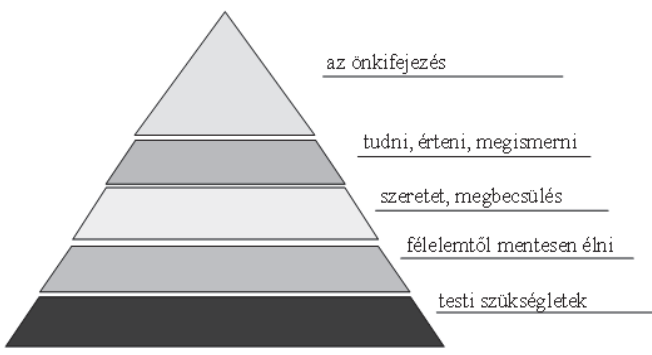

\begin{tabular}{|c|c|c|}
\hline 5. szint: & Önmegvalósitás szükséglete & $\begin{array}{l}\text { Az ember magasabb } \\
\text { rendü célkitüzései }\end{array}$ \\
\hline & $\begin{array}{l}\text { Én szükségletek (státusz) } \\
\text { hatalom, érvényesülés }\end{array}$ & \multirow{2}{*}{$\begin{array}{l}\text { Pszichológiai } \\
\text { életben maradás }\end{array}$} \\
\hline 3. szint: & $\begin{array}{l}\text { Szociális szükségletek } \\
\text { (csoporthoz tartozás) }\end{array}$ & \\
\hline & $\begin{array}{l}\text { Biztonság és védettség } \\
\text { szukséglete }\end{array}$ & \\
\hline 1. szint: & $\begin{array}{l}\text { Vitális szükségletek } \\
\text { alapvetô szükségletek: } \\
\text { alvás, evés, stb. }\end{array}$ & Testi életben maradás \\
\hline
\end{tabular}

1. ábra A. Maslow: Szükséglethierarchia piramis

Nem könnyű feladat, különösen a mai rohanó, feszültségekkel és létbizonytalansággal teli pénzcentrikus világunkban, ahol az önmegvalósítás magasabb szintjeinek eléréséhez szükséges családi és társadalmi feltételek nem mindig biztosítottak. Azokban a családokban, ahol a vitális, alapvető testi szükségletek - 1 . szint - kielégítése is nehézségekbe ütközik, a felső szint elérhetetlennek túnik.

A káros stressz - distressz - okozta adaptációs betegségek a lakosság széles rétegeit érintik, közük a fiatalokat is ... évről-évre szinte megduplázódik a hiperaktív, magatartási zavaroktól szenvedő, szorongásos tünetekkel, tanulási nehézségekkel küzdő gyermekek száma, nem beszélve a különböző drogok önpusztító, személyiségromboló hatásairól.

A félelem, a depressziós és szorongásos tünetek hátterében igen gyakran önértékelési zavarok, és a külső körülmények okozta önmegvalósítási akadályok húzódnak meg (munkanélküliség, létbizonytalanság, kiszolgáltatottság, stb.). Ha nincs módunk a bennünk lévő kincseinkből másoknak adni, az hosszú távon betegséghez vezet.

„Ami bennünk van, az kiélést követel ... Az a legnagyobb múvészet, hogy vitalitásunkat a Természettöl megszabott módon és tempóban éljük." - írja Selye János [10]
Mentális,- érzelmi,- testi tüneteink nem az ellenségeink, hanem belső-énünk üzenetei, életünk főútvonala irányába terelgető jelzőtábláink. Konfliktusaink, megpróbáltatásaink mind-mind arra szólítanak fel, hogy mozduljunk ki a holtpontról, szabaduljunk meg félelmeinktől és ismerjük meg a bennünk szunnyadó értékeket, képességeket, melyekkel önmagunkat és a világot is szebbé és boldogabbá varázsolhatjuk.

Gyakran tesszük fel azt a kérdést: Merre menjek? Mit csináljak? Miért vagyok beteg? Hogyan oldjam meg a problémáimat és konfliktusaimat?

Külső segítségért kiáltunk, miközben a megoldókulcs bennünk van: "Ismerd meg önmagad, és tudni fogod a sorsodat." - szól a delphoi jósda felirata.

„Aki tisztában van képességeivel, gyengéivel vagy önmagával - az megfelelö én-erövel, belső stabilitással bírva könnyebben eligazodik a világban, az képes az igényei és kínálkozó lehetőségei közötti összhangot megteremteni, reális célokat kitüzni, önfejlődésének irányt adni ... Az önismeret sokféle módon érhető el és ezek mindegyik megnövekedett belső harmóniához vezet." Csíkszentmihályi Mihály [9]

$\mathrm{Az}$ önismereti módszerek széles skálája áll rendelkezésünkre az elinduláshoz. A vonatkozó két legismertebb tudományterület ebben a pszichológia és a grafológia, melyek 
párhuzamos és intenzív fejlődése az 1800-as évek közepétől indult el.

A pszichológia kezdetben fiziológiai irányt vett, sokáig a pszichológiai kísérleteket természettudósok végezték. Később a pszichológián belül igen erőteljes differenciálódás indult be, amely még ma is tart.

A grafológiának (lásd: Alapfogalmak), mint önismereti tudománynak az alapjait J.H. MICHON abbé rakta le. Maga a grafológia elnevezés is tőle származik. 1875-ben megjelent könyvében és későbbi munkáiban - „A grafológia rendszere" címú múvében részletesen foglalkozik a kézírás (lásd: Alapfogalmak) neuro-fiziológiai és pszichológiai összefüggéseivel, azt írja: „A lélek az, amely közvetlenül ir és beszél." Rendszere személyiségközpontú, az embert kézírásán keresztül, EGÉSZ-ben, - mentális,é érzelmi,testi dimenzióiban - komplex módon vizsgálja.

J.H. Michon sok tekintetben több mint 50 évvel megelőzte korát - lerakta a pszichoanalízis alapjait. 60 évvel Michon abbé halála után a neuro-fiziológiai és pszichológiai kutatások bebizonyították, az írás valóban „agyírás”, a grafológia önálló tudomány.

Ma a grafológia és a pszichológia tudománya egymást kiegészítő, megerősítő önismereti módszerként működik. A hazai és külföldi szakemberek közül sokan dolgoznak egyszerre mindkét területen.

Tekintettel arra, hogy a lélek titkainak és csodáinak feltárása, az ember megismerése nem könnyű feladat, ez indokolt szükségszerűség.

Minden emberismereti tudománynak, így a grafológiának és pszichológiának is vannak gyenge láncszemei, mégpedig vizsgálatuk tárgyának bonyolultsága, vagyis maga az EGÉSZ ember, annak egyszeri, megismételhetetlen, semmihez nem hasonlítható létezése.

Az ember földi és kozmikus, háromdimenziós létezésével, mindazokkal a külső és belső tényezőkkel, körülményekkel, melyek hatással vannak a személyiség fejlődésére, változásaira, teljes egészében soha nem ismerhető meg.

Ezt a bonyolultságot szemlélteti a 2 . ábra.

A három dimenzió mindegyikében mindig ott van a másik kettő is egymástól elválaszthatatlanul!

A mentális,- érzelmi,- testi „mozgások” és összefüggések variációs lehetőségei végtelenek.

$\mathrm{Az}$ ember egyedisége, lelkének, testének bonyolultsága,- a személyiség sokoldalúsága komplex- és rugalmas megközelítést igényel.

A személyiségelemzés a szakembertől lelkiismeretes, felelősségteljes, alapos, precíz és kitartó munkát követel. Analizáló- és szintetizáló képességet, holisztikus gondolkodás- és szemléletmódot, intuíciót, beleérző- és együttérző képességet - empátiát -, a vizsgált egyén feltétel nélküli elfogadását, szeretetét és segíteni akarást, és nem utolsó sorban a különböző önismereti módszerek, emberismereti tudományok összehangolt alkalmazását és kontrollját. Mindezek együtt biztosítékai a sikeres személyiségfejlesztésnek. [5], [6]

Ilyen komplex elemzési rendszer lehet: a különböző pszichológiai tesztek, az írás- és rajzelemzés, a múszeres vizsgálatok együttese. 


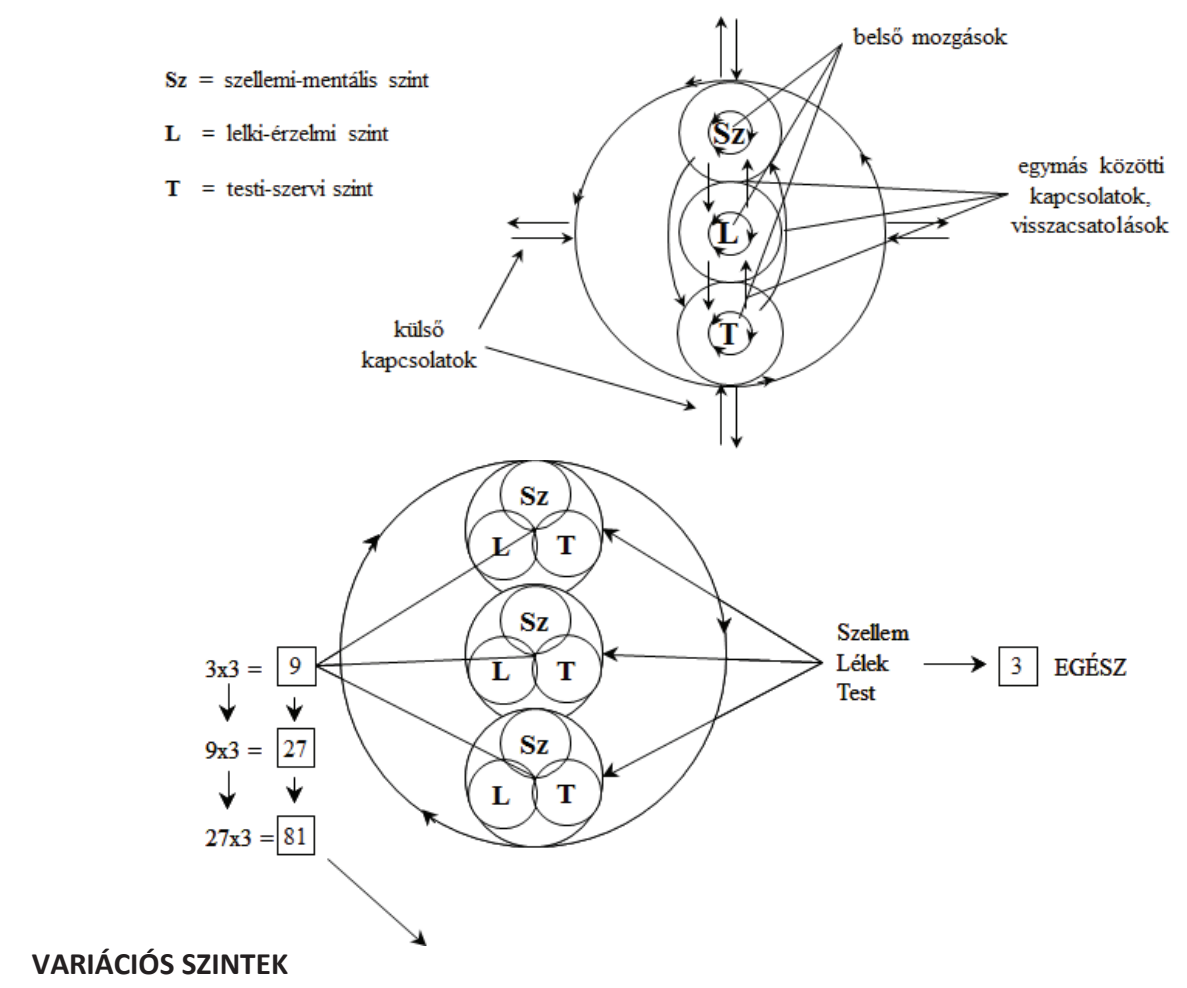

a) alap:

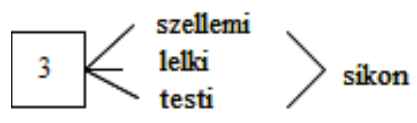

b)

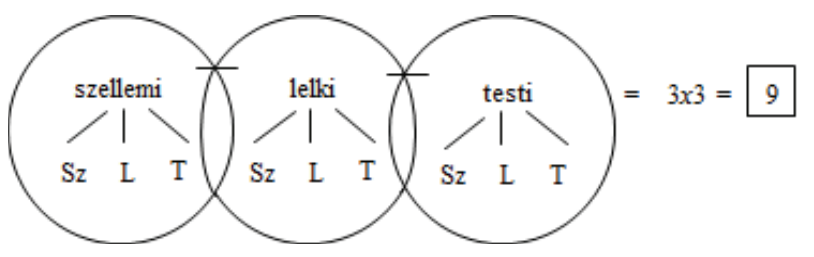

c)

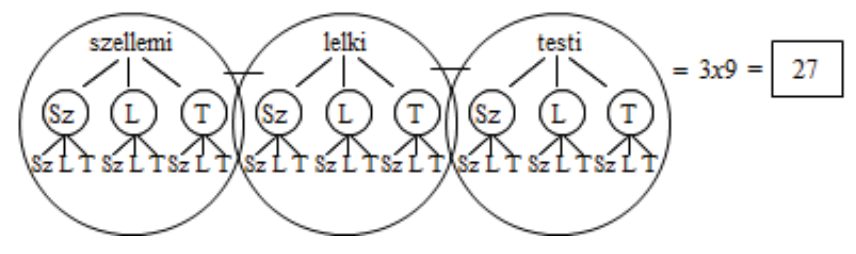

d)

$3 \times 27=81$ és így tovább

2. ábra A személyiségelemzés dimenziói

Az ember mentális-érzelmi-testi hármas egysége, összetettsége a többlépcsős mélyelemzés tükrében 
Az alábbi példa ezt szemlélteti, és arra hívja fel a figyelmet, hogy már gyermekkorban érdemes az önismerettel foglalkozni.

Esetleírás: „Jó kőmüves lesz belőled fiam." (Részlet Márfy Anna: „Benned is ott van.” címú most készülő könyvéből.

Levente 15 éves, az általános iskola 8. osztályos tanulójaként matematikából és még énekből is bukásra áll. Levente okos, értelmes, jó kézügyességú, érzékeny múvészlélek, akinek súlyos magatartási problémái miatt állandó konfliktusai vannak otthon és az iskolában is. Lázadó viselkedésével próbálja felhívni a környezetében élők figyelmét belső értékeire, tehetségére. Kétségbeesetten kiált segítségért, támogatásért, elismerésért immár jó pár éve.

Levente édesapja az építőiparban dolgozott, ezért úgy gondolta, hogy fiának is jó lesz a kőmúves szakma.

A mellékelt rajzok önmagukért beszélnek: Levente óriási szabadságvágyáról, alkotó fantáziájáról, feszültségeiről, a korlátokat ledönteni próbáló individualisztikus, kreatív szárnyalásairól, és jelenlegi - számára kilátástalannak túnő _ helyzetének, problémáinak visszatükröződéséről.

Levente Fa-rajz tesztje a mellett, hogy megmutatja intellektuális képességeit, adottságait, sokoldalúságát, önmaga stabilitását, vágyait, rávilágít átélt lelki traumáinak tudat alatt megtalálható nyomaira is (lásd: nyírfa levágott ágait a 2. fa rajzon): Levente - évekkel korábban - egy súlyos közlekedési baleset áldozata lett. Hosszú ideig feküdt kórházban, intenzív osztályon.

Milyen okulni való tanulságokat hordoz ennek a 15 éves kamasz fiúnak a története?

Levente képességeinek időben való felismerésével, személyiségének és temperamentumának megfelelő, differenciált kezelésével, rajztehetségének elismerésével és fejlesztésével, bal agyféltekéjének, figyelemkoncentrációjának - már az iskolai évek elejétől - történő erősítésével megelőzhetőek lehettek volna a környezetében élőkkel való súlyos konfliktusai, lelki problémái, motivációs,- és pályaválasztási nehézségei.

Szomorú tények ezek! Mindenki Leventét akarta „kezelésbe” venni, holott a háttérben éppen az ítéletet alkotó felnőttek, szülők, pedagógusok és az a fajta oktatási,- és nevelési rendszer a „ludas”, amely az Ő esetében is hibás döntéseket hozott információ, empátia és emberismeret hiányában.

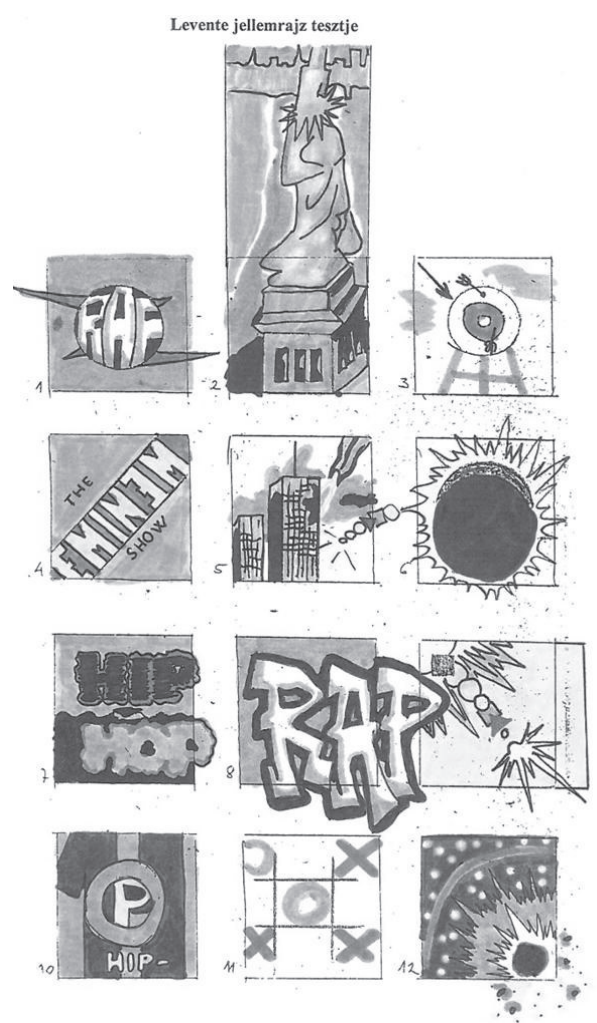



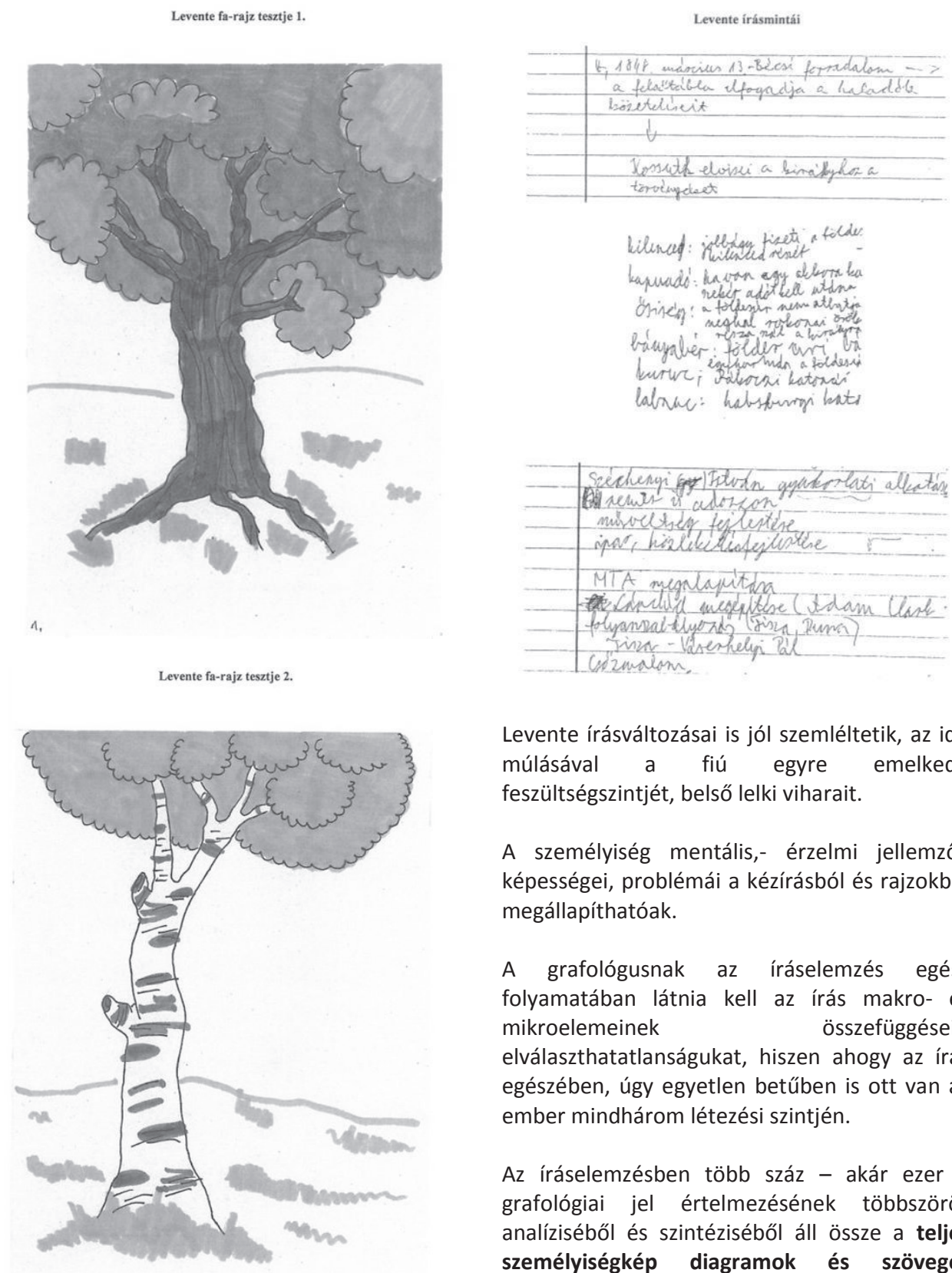

Levente írásváltozásai is jól szemléltetik, az idő múlásával a fiú egyre emelkedő feszültségszintjét, belső lelki viharait.

A személyiség mentális,- érzelmi jellemzői, képességei, problémái a kézírásból és rajzokból megállapíthatóak.

A grafológusnak az íráselemzés egész folyamatában látnia kell az írás makro- és mikroelemeinek összefüggéseit, elválaszthatatlanságukat, hiszen ahogy az írás egészében, úgy egyetlen betúben is ott van az ember mindhárom létezési szintjén.

Az íráselemzésben több száz - akár ezer grafológiai jel értelmezésének többszörös analíziséből és szintéziséből áll össze a teljes személyiségkép diagramok és szöveges értékelések formájában.

Néhány képesség, tulajdonság - a sok közül -, melyet vizsgál és értékel a grafológia. Ezt szemléltetik a következő diagramok. 

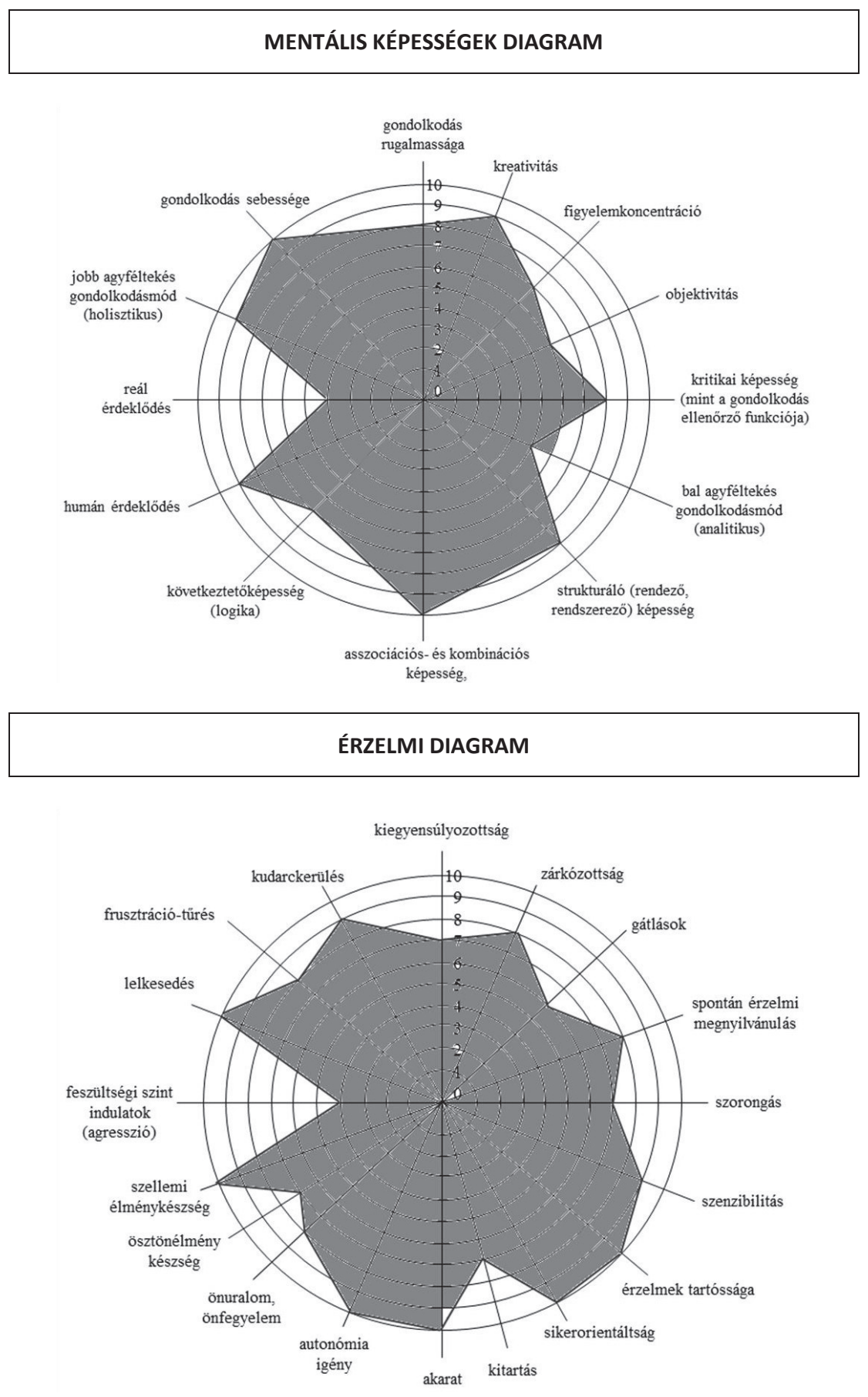

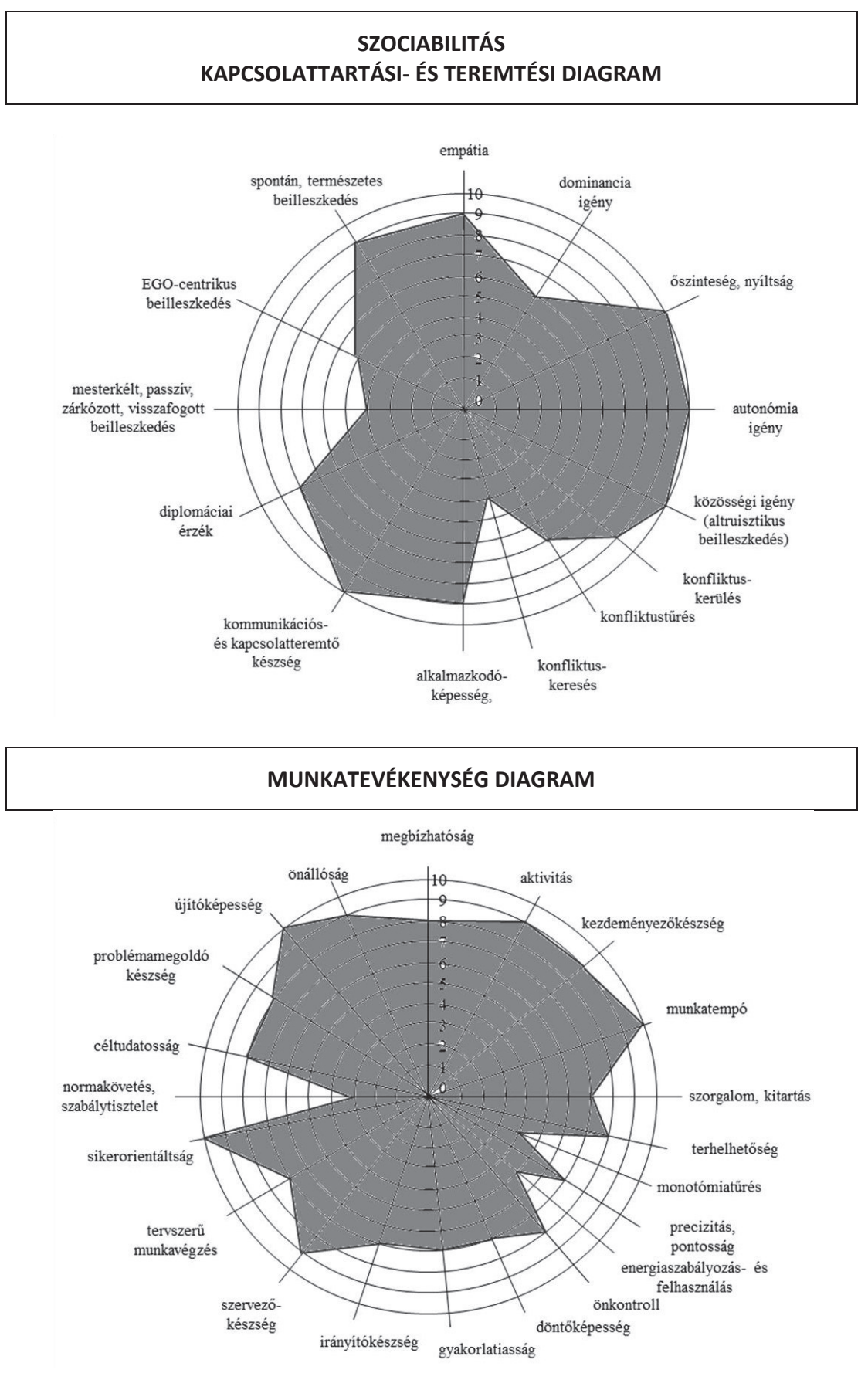


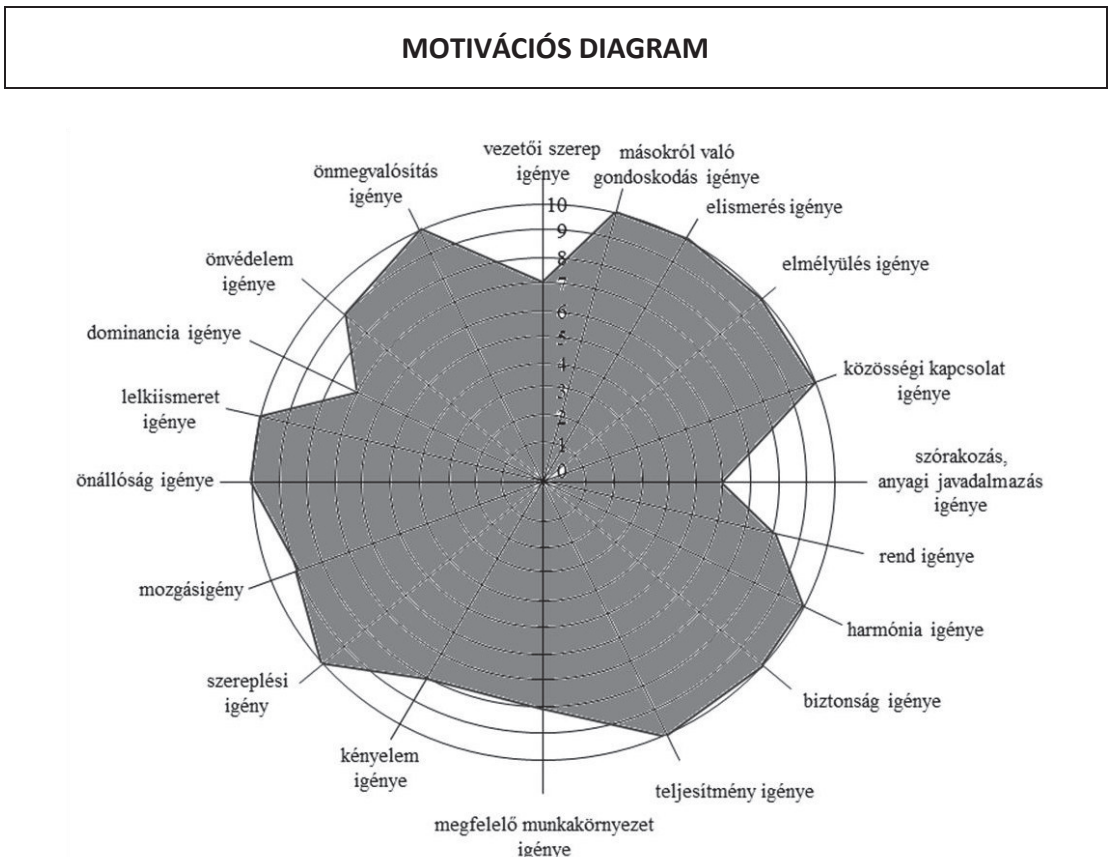

\section{A grafológia megbízható önismereti tudomány.}

A mélyebb önismereten át támogatta a fiatalok sikeresebb önmegvalósítását, azon belül is:

Az íráselemzés módszeregyüttese nagy segítség az önmeghatározásban, az egészséges önszabályozás támogatásában, annak felismerésében, hogy az ember önmegvalósításának, motiváló erejének, személyes kontrolljának a forrása nem más, mint önmaga, mert:

„A motiváció belülröl az egyénböl fakad, azt nem lehet létrehozni, hanem felszínre kell hozni." [11]

A Szolnoki Főiskolán 2013. év őszén indult pályázati és képzési programok keretében több mint száz diák vett részt önismeretfejlesztésben és a grafológia tudományának megismerésében.

Milyen területeken adott valami pluszt a hallgatók számára a grafológia?

- önelfogadást,

- önbizalom megerősödését,

- mentális-érzelmi

egyensúly stabilizálódását

- társas kapcsolatok erősödését,

- hatékonyabb konfliktuskezelést,

- rugalmasabb problémamegoldást,

- képességek, adottságok feltérképezését,

- pályaorientációt,

- képességeiknek, adottságaiknak megfelelő tanulási módszerek kiválasztását,

- motivációt,

- annak felismerését, hogy: Minden embernek szüksége van valamilyen célra $a z$ életben, amit tiszteletben tart és büszke hogy dolgozik érte, mert csak így maradhat egészséges ... A pénz például sohasem lehet végsö cél, önmagában nincs értéke, csak eszközül szolgálhat egy olyan végcél eléréséhez, amely 
Márfy Anna: Önismeret az önmegvalósításban a grafológia eszközeivel

önmagában értékes számunkra ... A kiegyensúlyozott boldog emberekben ez a cél szinte kivétel nélkül mindig az önkifejezés, és a többiek jóindulatának és nagyrabecsülésének megszerzése iránti vágy." [10]

A tanulmányban található képek és ábrák színes, eredeti változata megtalálható a folyóirat szerkesztőségében.

\section{ALAPFOGALMAK}

\section{Személyiség}

„Az egyes emberi lény teljes szellemi struktúrája, fejlődése bármely adott fokán. Felöleli $a z$ emberi jellem minden összetevőjét: $\quad a z$ intellektust, $a$ temperamentumot, a készségeket, az erkölcsiséget, és minden olyan attitüdöt, amely benne élete során kiépült." [3] (Narren H.C. - Carmichael)

„Az egyénnek biológiai és társadalmi adottságai, az ezek kölcsönhatása által determinált és széles skálában kibontakozó tulajdonságai alkotják az egyénre jellemzó alkati és funkcionális dinamikus egységét, amelyet személyiségnek nevezünk. Elemeire bontva: az egyén kognitiv, affektív, motivációs - akarti, fiziológiai és morfológiai adottságainak dinamikus struktúrája, szervezett egység ..." [12]

\section{Kézírás}

„Írott beszéd, papíron rögzített mozgás, agytevékenység, a bennünk lévő ösztönerők, késztetések által keltett iazomfeszültségeknek az emberi tudat által felülbírált képi megjelenitése - tudatos- és tudattalan folyamatok tükre - a személyiség lenyomata." [1], [2],[3]

\section{Grafológia}

$\mathrm{Az}$ íráselemzés tudománya (grafo = írás (elemzés) - logosz = tudomány)

„Az a tudomány, amely az ember kézírása segítségével kutatja a papíron rögzített mozgást, és a mozgást létrehozó ember jelleme, ismeretei, állapota és vágyai, azaz személyisége közötti összefüggéseket." [1] [2],[3]

A grafológia személyiségfeltáró- és alkalmasságot vizsgáló módszer.

\section{IRODALOMJEGYZÉK}

[1] Agárdi Tamás - Szidnai László (SZERK). (1998): A grafológia kézikönyve. Kiadó: Grafológiai Intézet. Budapest

[2] Agárdi Tamás - Gulyás Jenő István (szerk.) (1985): A mai magyar grafológia. Kiadó: Grafológiai Intézet. Budapest

[3] F. Visnyei Irma - Gulyás Jenő István - Katona Ágnes - V. Vékony Györgyi (2000 és 2001): A grafológia alaptankönyve. 1. és 2. kötet. Kiadó: Grafodidakt Grafológusképző és Személyiségfejlesztő Központ. Budapest

[4] Márfy Anna (2002): Miről árulkodnak az oválok? Grafodidakt Magazin. 2002. 3. évf. 4. szám

[5] Márfy Anna (2002/6): Indokolt-e? Kontrollmódszerek alkalmazása a grafológiában és a pszichológiában. Grafológia. VIII. évf. (85.)

[6] Márfy Anna (2002): A túlzott analízis veszélyei. Hol a valódi grafológiai sztenderd? Nemzetközi Grafológiai Szemle. X. évf. 1. szám

[7] C.G. Jung (1999): Beszélgetések és interjúk. Kossuth Könyvkiadó. Budapest

[8] Rita L. Atkinson - Richard C. Atkinson - Edward E. Smith - Daryl J. Bern (1995): Pszichológia. Osiris Századvég Kiadó. Budapes

[9] Csíkszentmihályi Mihály (2001): FLOW. Az áramlat. Akadémiai Kiadó. Budapest 
Interdiszciplináris rovat

[10] Selye János (1976. és 1969): Stressz distressz nélkül és Az életünk és a stressz. Akadémiai Kiadó. Budapest

[11] Harold F.O. Neil, JR. Michael Drillings (szerk.) (1999): Motiváció. Elmélet és kutatás. Vince Kiadó Kft. Budapest

[12] Juhász Pál - Pethő Bertalan (1983): Általános pszichiátria 1. Pszichopatológia. Medicina Könyvkiadó.Budapest

[13] Tringer László (1992): A gyógyító beszélgetés. Kiadó: Semmelweis Orvostudományi Egyetem Képzéskutató, Oktatástechnológiai és Dokumentációs Központ. Budapest 